\title{
Modelling and Forecasting of Total Area, Irrigated Area, Production and Productivity of Important Cereal Crops in India towards Food Security
}

\author{
Nalinikanta Choudhury ${ }^{1}$, Sumeet Saurav ${ }^{2}$, Rajeev Ranjan Kumar ${ }^{2 *}$ and \\ Neeraj Budhlakoti ${ }^{1}$ \\ ${ }^{1}$ Centre for Agricultural Bioinformatics, ${ }^{2}$ Discipline of Agricultural Statistics, \\ ICAR-IASRI, New Delhi-110012, India \\ *Corresponding author
}

\section{A B S T R A C T}

\begin{tabular}{|c|c|}
\hline Key & \multirow{4}{*}{$\begin{array}{l}\text { In this study, under the background of over all food security in India, an attempt have been } \\
\text { made to analyse behavior of area, irrigated area, production and productivity of rice, wheat } \\
\text { and maize. The descriptive statistics of area, irrigated area, production and productivity of } \\
\text { the given crop have been analysed. For the modelling and forecasting purpose Box- }- \text { the } \\
\text { Jenkins ARIMA modelling technique has been used to analyse the information from } 1951 \\
\text { through } 2015 \text {. The result of the study reveals that the yield of rice, wheat and maize in } \\
\text { India would be } 2.57 \text { tons/ha, } 3.14 \text { tons/ ha and } 3.13 \text { tons/ha in } 2021 \text { respectively. The total } \\
\text { production of rice, wheat and maize will be increased by } 5319 \text { thousand tons, } 5.5 \text { thousand } \\
\text { tons and } 3838 \text { thousand tons in total respectively. It also emphasizes the need for increase } \\
\text { in the per hectare yield of these crops in India in order to get a sustainable development of } \\
\text { Agriculture. Forecasting of area, irrigated area, production and productivity will be helpful } \\
\text { to solve the food security problem and for development of policy research for the major } \\
\text { food crops. }\end{array}$} \\
\hline $\begin{array}{l}\text { Time } \\
\text { foreca } \\
\text { ARIN } \\
\text { Area, } \\
\text { Irriga } \\
\text { Produ }\end{array}$ & \\
\hline Article Info & \\
\hline & \\
\hline
\end{tabular}

\section{Introduction}

Global food security is one of the major concerns in the era of twenty first century. The arable land degraded day by day whereas the demand for more food increased at an alarming rate. There is need for serious concern to increase the food production of major food crops like rice, wheat, maize. To improve the overall food security situation in India, there have to analyse behaviour of total production along with the total area, irrigated area and productivity of three major food crops rice, wheat and maize. This will create a strategic development for the future food security. The agriculture and allied sector continues to play an important role for sustainable growth and development of the Indian economy. Agriculture accounts for considerable importance in India's economic development, as it provides food for more than 1.25 billion people. It generates employment for about $54.6 \%$ of the total population. Production of food grain covers the dominant part of the cropped area (nearly $65 \%$ ) in Indian agriculture. In the production of rice, wheat and maize, India's position in the world is second (Khatkar et al., 2016). Rice, wheat and maize are the major cereals crops in India. The green revolution in India 
brought in to lime light due to rice and wheat in the year 1965-66. The growth rate for the agriculture and allied sectors in India is estimated to be 4.1 percent for the year 201617 (Economic Survey, 2016-17). Therefore rice, wheat and maize will a sustainable role in growth of agriculture and food security in India. Rice has become a highly strategic and priority commodity for food security in India, majorly south and eastern states whereas the north and western states follows a feeding pattern of wheat and maize. Cereal production and food security are threatened by climate change, stagnating yields and environmental degradation in India.

In the world's rice production, India stands second-largest producer after China and one of the largest consumer and which accounts for $22.3 \%$ of global production. It is mainly cultivated in eastern and southern states whereas Punjab state has the highest productivity in India. To increase the production and productivity of rice, government of India has launched several programs such as National Food Security Mission (NFSM) and Bringing Green Revolution in Eastern India (BGREI) during 2007-08 and 2010-11 respectively.

After Rice, wheat is the second principal sources of food grain in India having 12\% share in total world wheat production. It has high calorie, and protein intake for most of the people of India (Sahu et al., 2015). It has been traditionally cultivated in major fertile and irrigated area of northern region of India. Punjab and Haryana of northern plains in India have been the leader in wheat production and on total production Uttar Pradesh is on the top list. Mainly three wheat species have been cultivated in India namely T. aestivum, T. durum and T. dicoccum.

Maize is cultivated round the years in some part of the country but kharif Maize crop in predominantly cultivated in kharif season only with an approximation of 85 percent of area covered under the Kharif season crops (Joshi, 2005). After rice and wheat crops, maize is the third most significant cereal crop in India. Its share in total food grain production is near about 9 percent. Due to its highest yield potential among the cereal crops, it is called as the queen of the cereals. It is considered as one of the most versatile crop as it has a vast adaptability under varied agro-climatic conditions. The main areas of cultivation of maize comprise of extreme semi-arid to sub humid and humid regions. The crop is mainly cultivated in low and midhill areas of western and northeastern regions in India.

Forecasting area under the crop, irrigated area under crop, Production and productivity are the essential parameter for founding a support policy decision regarding the food security, effective land use allocation, technological issues and environmental issue etc. Using a proper statistical technique to represent the statistical forecast with desired precisions well in advance. Forecasting using univariate time series model is known as auto regressing integrated moving average (ARIMA) model. It is also called as Box and Jenkin model (Box et al., 1976). Among the available stochastic time series models, ARIMA model is one of the popular technique to forecast using observed data with minimum forecast error.

Debnath et al., (2013) forecasted cultivated area and production of cotton in India using Autoregressive Integrated Moving Average (ARIMA) method up to the year 2020. Awal et al., (2011) made the best effort to develop a short run forecasting model of rice production in Bangladesh specifically for Aus, Aman, and Boro rice production. Iqbal et al., (2005) also practiced the ARIMA Model for forecasting wheat area and production in Pakistan from 2002 to 2012.Similarly, 
Rachana et al., (2010) have been studied for forecasting pigeon pea production in India by successfully using ARIMA Model. Celik (2016) forecasted the annual production amounts of some cereal like wheat, barley and maize produced in Turkey and predicted production amounts for the period 2016 to 2025. Michel et al., (2013) presented eight statistical models for analyzing yield time series and compare their ability to predict wheat yield at the national and regional scales. Hafner (2003) stated a test of the applicability of two general models for 188 nations to time series of maize, rice and wheat yields to characterize past yield trends and to analyse the relative importance of various trends on a global scale. Also determine what factors might be responsible for the presence of slowing yield growth and yield decline in some nations.

\section{Materials and Methods}

The data consists of the information on area (in thousand hectare), irrigated area (in thousand hectare), production (in thousand $\mathrm{kg}$ ) and productivity (in thousand tons per hectare) of rice, wheat and maize for the period 1951 to 2015. These are collected from Ministry of Agriculture \& Farmers Welfare, Govt. of India website. To observe the nature of each factor, there is need to calculate descriptive statistics to draw some basic idea about the data set.

These descriptive statistics offer simple summaries about the data and the measures. The descriptive statistics study that used for study are maximum, minimum, mean, median, skewness, kurtosis etc. to describe the pattern of the series and draw a consensus under consideration. Based on the descriptive statistics, the series is forecasted for the years to come in order to take appropriate measure for policy making. So for forecasting purpose, the study adopted ARIMA model which is also called as Box -Jenkins methodology. The collected data is distributed as model building for the period of 1951-2010 and as model validation for the period of 2011-2015 and a prediction for over a period of 6 years is taken in to consideration. Models are compared as Minimum Error (ME), Root Mean Square Error (RMSE), Mean Absolute Error (MAE), Mean Percent Error (MPE), Mean Absolute Percentage Error (MAPE), and Mean Absolute Square Error (MASE).

\section{ARIMA methodology}

The annual data on rice, wheat and maize cultivated area, production, productivity and irrigation area over a period of 1951 to 2015 are used for forecasting the future values using Auto Regressive Integrated Moving Average (ARIMA) models. The ARIMA methodology is also called as Box-Jenkins methodology (Box et. al., 1976). The BoxJenkins procedure is concerned with fitting a mixed ARIMA model to a given set of data.

The main objective in fitting ARIMA model is to identify the stochastic process of the time series and predict the future values accurately. A stochastic process is either stationary or non-stationary. The first thing to be noted that most time series are non-stationary and the ARIMA models refer only to a stationary time series (Chatfield, 1988). Since the ARIMA models refer only to a stationary time series the first stage of Box-Jenkins model is for reducing non-stationary series to a stationary series by taking first order differences. In general, an ARIMA model is characterized by the notation ARIMA (p,d,q) where, $p, d$ and $q$ denote orders of auto-regression, integration (differencing) and moving average respectively.

The notation AR (p) refers to the autoregressive model of order $p$. The AR (p) model is written as, 
$X_{t}=c+\sum_{i=1}^{p} \propto_{i} X_{i}+\mu_{t}$

Where $\alpha_{1}, \alpha_{2}, \alpha_{3} \ldots \alpha_{\mathrm{p}}$ are the parameters of the model, $\mathrm{c}$ is a constant and $\mu_{\mathrm{t}}$ is white noise. Sometimes the constant term is omitted for simplicity.

The main stages in setting up a Box-Jenkins forecasting model are as follows:

Identification

Estimating the parameters

Diagnostic checking

Forecasting

\section{Results and Discussion}

Tables 1, 2 and 3 display descriptive statistics with respect to area, irrigated area, production and productivity in rice, wheat and maize in India from 1951 to 2015 respectively.

The descriptive statistics demonstrates the mean, maximum and minimum values along with other statistical properties. From Table 1 it is clear that there is huge difference in the minimum and maximum value of irrigated area, production and productivity of rice during the study period. The average irrigated area and productivity under rice are found to be 17878thousand hectare and 1.468 tons per hectare respectively. It is remarked that the increase in irrigated area will increase the productivity of rice in India. Similarly, in table 2, the average wheat area and production are 21072.97 thousand hectare and 42.6310 thousand tons during the period 1951-2015 respectively. As compared to this, the average irrigated area and productivity are 15380.75 thousand hectare and 1.799 tons per hectare respectively. This shows that the wheat irrigated area and productivity has been increased from year by year that leads to a bumper production of wheat over certain period of time. Likewise, in table 3, the average maize area under cultivation and production have a mean of 5913 thousand hectare and 8908 thousand tons over a period of time from 1951-2015 respectively. As similar to this, the average irrigated area and productivity are 1151 thousand hectare and 1.385 thousand per hectare respectively during the study period. As compared to wheat production, maize production cannot be increased at that pace. The future pattern of area, irrigated area, production and productivity of these three major food crops should be increased towards the nutritional and food security for the sustainable development of human resource with the above scenario of productivity and total production of rice, wheat and maize.

After the descriptive statistics, among several competitive models available, the suitable fitted ARIMA model have been chosen based on the methods provided in the material and methods section. ARIMA model is generally applied for stationary time series data. The time series properties of stationary and nonstationary are checked applying Augmented Dickey Fuller Test. The Augmented Dickey Fuller (ADF) Tests results are estimated with level and first difference. The detail result of the ADF test is given in the table 4 .

The result shows that, all the variables are non-stationary at level but stationary at first difference. In all the cases null hypothesis of non-stationary at level data is accepted but the same null hypothesis is rejected at first difference data. The first step of applying Box-Jenkins forecasting model is to identify the appropriate order of ARIMA (p, d, q) model. Identification of ARIMA model implies selection of order of AR(p), MA(q) and $I(d)$. The order of $d$ is estimated through $\mathrm{I}(1)$ or $\mathrm{I}(0)$ process of unit root stationary tests. 
Table.1 Descriptive statistics for rice in India from 1951-2015

\begin{tabular}{|l|l|l|l|l|l|l|}
\hline & \multicolumn{1}{|c|}{ Range } & \multicolumn{1}{|c|}{ Minimum } & \multicolumn{1}{|c|}{ Maximum } & \multicolumn{1}{|c|}{ Mean } & Skewness & Kurtosis \\
\hline Area & 15465 & 29991 & 45456 & 39270.40 & -0.570 & -0.835 \\
\hline Irrigated Area & 16934 & 9650 & 26584 & 17878.74 & 0.203 & -1.276 \\
\hline $\begin{array}{l}\text { Production in } \\
\text { '000 tons }\end{array}$ & 86070 & 20576 & 106646 & 59659.28 & 0.247 & -1.294 \\
\hline $\begin{array}{l}\text { Productivity } \\
\text { (Kg/ha) }\end{array}$ & 1794 & 668 & 2462 & 1468.83 & 0.294 & -1.225 \\
\hline
\end{tabular}

Table.2 Descriptive statistics for wheat in India from 1951-2015

\begin{tabular}{|l|c|c|c|c|c|c|}
\hline & Range & Minimum & Maximum & Mean & Skewness & Kurtosis \\
\hline Area & 22454 & 9624 & 32078 & 21072.97 & -0.285 & -1.171 \\
\hline $\begin{array}{l}\text { Irrigated } \\
\text { Area }\end{array}$ & 26812 & 3402 & 30214 & 15380.75 & -0.053 & -1.381 \\
\hline $\begin{array}{l}\text { Production } \\
\text { in '000 tons }\end{array}$ & 88.70 & 6.1800 & 94.8800 & 42.63 & 0.236 & -1.294 \\
\hline $\begin{array}{l}\text { Productivity } \\
\text { (Kg/ha) }\end{array}$ & 2524 & 653 & 3177 & 1799.71 & 0.052 & -1.478 \\
\hline
\end{tabular}

Table.3 Descriptive statistics for maize in India from 1951-2015

\begin{tabular}{|l|c|c|c|c|c|c|}
\hline & Range & Minimum & Maximum & Mean & Skewness & Kurtosis \\
\hline Area & 6026 & 3159 & 9185 & 5913.69 & 0.358 & -0.005 \\
\hline $\begin{array}{l}\text { Irrigated } \\
\text { Area }\end{array}$ & 2080 & 369 & 2449 & 1151.66 & 0.551 & -0.120 \\
\hline $\begin{array}{l}\text { Production } \\
\text { in '000 tons }\end{array}$ & 22531 & 1729 & 24260 & 8908.71 & 1.239 & 0.841 \\
\hline $\begin{array}{l}\text { Productivity } \\
\text { (Kg/ha) }\end{array}$ & 2129 & 547 & 2676 & 1385.14 & 0.799 & -0.271 \\
\hline
\end{tabular}

Table.4 Augmented Dickey-Fuller Test

\begin{tabular}{|l|l|l|l|}
\hline & & \multicolumn{2}{|c|}{ ADF Test } \\
\hline & & $\mathrm{p}$ value at level & P value at 1st difference \\
\hline \multirow{4}{*}{ Rice } & Area & 0.5393 & $<0.01$ \\
\cline { 2 - 4 } & Irrigated Area & 0.06035 & $<0.01$ \\
\cline { 2 - 4 } & Production & 0.3485 & $<0.01$ \\
\cline { 2 - 4 } & Productivity & 0.5825 & $<0.01$ \\
\hline \multirow{5}{*}{ Wheat } & Area & 0.5008 & $<0.01$ \\
\cline { 2 - 4 } & Irrigated Area & 0.4395 & $<0.01$ \\
\cline { 2 - 4 } & Production & 0.1073 & $<0.01$ \\
\cline { 2 - 4 } & Productivity & 0.4138 & $<0.01$ \\
\hline & Area & 0.9664 & $<0.01$ \\
\cline { 2 - 4 } & Irrigated Area & 0.9187 & $<0.01$ \\
\cline { 2 - 4 } & Production & 0.99 & $<0.01$ \\
\cline { 2 - 4 } & Productivity & 0.99 & \\
\hline
\end{tabular}


Table.5 Best ARIMA models fitted under rice, wheat and maize

\begin{tabular}{|l|l|l|l|l|l|l|l|}
\hline \multicolumn{2}{|c|}{} & Model & Sigma^2 & $\begin{array}{l}\text { Log } \\
\text { likelihood }\end{array}$ & AIC & AICC & BIC \\
\hline \multirow{4}{*}{ Rice } & Area & ARIMA(0,1,1) & 1052247 & -533.68 & 1073.36 & 1073.76 & 7079.83 \\
\cline { 2 - 8 } & $\begin{array}{l}\text { Irrigated } \\
\text { Area }\end{array}$ & ARIMA(0,1,1) & 670934 & -519.19 & 1044.38 & 1044.78 & 1050.86 \\
\cline { 2 - 8 } & Production & ARIMA(0,1,1) & 24463278 & -634.59 & 1275.19 & 1275.59 & 1281.66 \\
\cline { 2 - 8 } & Productivity & ARIMA(0,1,1) & 9178 & -382.12 & 770.25 & 770.65 & 776.73 \\
\hline \multirow{5}{*}{ Wheat } & Area & ARIMA(0,1,0) & 743087 & -522.9 & 1049.8 & 1050 & 1054.12 \\
\cline { 2 - 8 } & $\begin{array}{l}\text { Irrigated } \\
\text { Area }\end{array}$ & ARIMA(0,1,0) & 348198 & -498.64 & 1001.29 & 1001.49 & 10005.61 \\
\cline { 2 - 8 } & Production & ARIMA(1,1,0) & 11.02 & -166.64 & 339.29 & 339.69 & 345.76 \\
\cline { 2 - 8 } & Productivity & ARIMA(0,1,1) & 12641 & -392.12 & 790.25 & 790.65 & 796.72 \\
\cline { 2 - 8 } & Area & ARIMA(0,1,0) & 34305 & -424.49 & 852.97 & 853.17 & 857.29 \\
\cline { 2 - 8 } & $\begin{array}{l}\text { Irrigated } \\
\text { Area }\end{array}$ & ARIMA(0,1,1) & 16973 & -401.58 & 809.16 & 809.56 & 815.64 \\
\cline { 2 - 8 } & Production & ARIMA(3,1,2) & 1130153 & -535.1 & 1084.21 & 1086.21 & 1099.32 \\
\cline { 2 - 8 } & Productivity & ARIMA(1,1,2) & 19393 & -405.64 & 821.28 & 822.32 & 832.08 \\
\hline
\end{tabular}

Table.6 Comparison of accuracy of fitted model

\begin{tabular}{|l|l|l|l|l|l|l|l|l|}
\hline & & ME & RMSE & MAE & MPE & MAPE & MASE & ACF1 \\
\hline \multirow{5}{*}{ Rice } & Area & -9.47 & 1001.83 & 739.58 & -0.02 & 1.89 & 0.86 & 0.01 \\
\cline { 2 - 9 } & $\begin{array}{l}\text { Irrigated } \\
\text { Area }\end{array}$ & -3.06 & 799.97 & 526.68 & -0.17 & -0.17 & 0.83 & 0.01 \\
\cline { 2 - 9 } & Production & -2.47 & 4830.54 & 3452.02 & -1.24 & 6.32 & 0.72 & -0.07 \\
\cline { 2 - 9 } Wheat & Productivity & 0.98 & 93.61 & 68.26 & -0.66 & 5.15 & 0.73 & -0.09 \\
\hline \multirow{5}{*}{ Maize } & Area & 0.14 & 848.65 & 669.69 & -0.11 & 3.52 & 0.90 & -0.12 \\
\cline { 2 - 9 } & $\begin{array}{l}\text { Irrigated } \\
\text { Area }\end{array}$ & 0.04 & 580.93 & 443.79 & -1.03 & 3.85 & 0.80 & -0.09 \\
\cline { 2 - 9 } & Production & -0.01 & 3.23 & 2.50 & -2.72 & 8.24 & 0.84 & 0.01 \\
\cline { 2 - 9 } & Productivity & -0.18 & 109.80 & 84.09 & -0.69 & 5.58 & 0.82 & -0.01 \\
\cline { 2 - 9 } & Area & 0.04 & 182.34 & 137.30 & -0.06 & 2.40 & 0.84 & -0.04 \\
\cline { 2 - 9 } & $\begin{array}{l}\text { Irrigated } \\
\text { Area }\end{array}$ & 0.88 & 127.23 & 98.11 & -2.11 & 10.18 & 0.87 & -0.03 \\
\cline { 2 - 9 } & Production & 49.96 & 1001.21 & 728.11 & -2.03 & 9.50 & 0.77 & 0.01 \\
\hline
\end{tabular}

Table.7 Forecasted value of area, irrigated area, production, and productivity under rice

\begin{tabular}{|c|c|c|c|c|}
\hline Year & Predicted Area & $\begin{array}{c}\text { Predicted Irrigated } \\
\text { Area }\end{array}$ & $\begin{array}{c}\text { Predicted } \\
\text { Production }\end{array}$ & $\begin{array}{c}\text { Predicted } \\
\text { Productivity }\end{array}$ \\
\hline 2016 & 44442 & 26793.3 & 106964.70 & 2441.31 \\
\hline 2017 & 44655 & 27056.72 & 108294.50 & 2468.06 \\
\hline 2018 & 44869 & 27320.13 & 109624.30 & 2494.81 \\
\hline 2019 & 45082 & 27583.55 & 110954.10 & 2521.56 \\
\hline 2020 & 45295 & 27846.97 & 112283.90 & 2548.31 \\
\hline 2021 & 45509 & 28110.39 & 113613.70 & 2575.06 \\
\hline
\end{tabular}


Table.8 Forecasted value of area, irrigated area, production, and productivity under wheat

\begin{tabular}{|c|c|c|c|c|}
\hline Year & Predicted Area & $\begin{array}{c}\text { Predicted Irrigated } \\
\text { Area }\end{array}$ & $\begin{array}{c}\text { Predicted } \\
\text { Production }\end{array}$ & $\begin{array}{c}\text { Predicted } \\
\text { Productivity }\end{array}$ \\
\hline 2016 & 32422.81 & 30632.94 & 90.93 & 2968.97 \\
\hline 2017 & 32767.63 & 31051.88 & 91.10 & 3004.62 \\
\hline 2018 & 33112.44 & 31470.81 & 92.80 & 3040.27 \\
\hline 2019 & 33457.25 & 31889.75 & 93.95 & 3075.91 \\
\hline 2020 & 33802.06 & 32308.69 & 95.29 & 3111.56 \\
\hline 2021 & 34146.88 & 32727.63 & 96.57 & 3147.21 \\
\hline
\end{tabular}

Table.9 Forecasted value of area, irrigated area, production, and productivity under Maize

\begin{tabular}{|c|c|c|c|c|}
\hline Year & Predicted Area & $\begin{array}{c}\text { Predicted Irrigated } \\
\text { Area }\end{array}$ & $\begin{array}{c}\text { Predicted } \\
\text { Production }\end{array}$ & $\begin{array}{c}\text { Predicted } \\
\text { Productivity }\end{array}$ \\
\hline 2016 & 9279.156 & 2388.98 & 26030.67 & 2757.712 \\
\hline 2017 & 9373.313 & 2419.264 & 27143.19 & 2845.562 \\
\hline 2018 & 9467.469 & 2449.548 & 28065.56 & 2926.78 \\
\hline 2019 & 9561.625 & 2479.832 & 29060.05 & 3002.245 \\
\hline 2020 & 9655.781 & 2510.116 & 30039.01 & 3072.718 \\
\hline 2021 & 9749.938 & 2540.4 & 30981.68 & 3138.859 \\
\hline
\end{tabular}

Fig.1 Observed and predicated area, irrigated area, production and productivity of rice
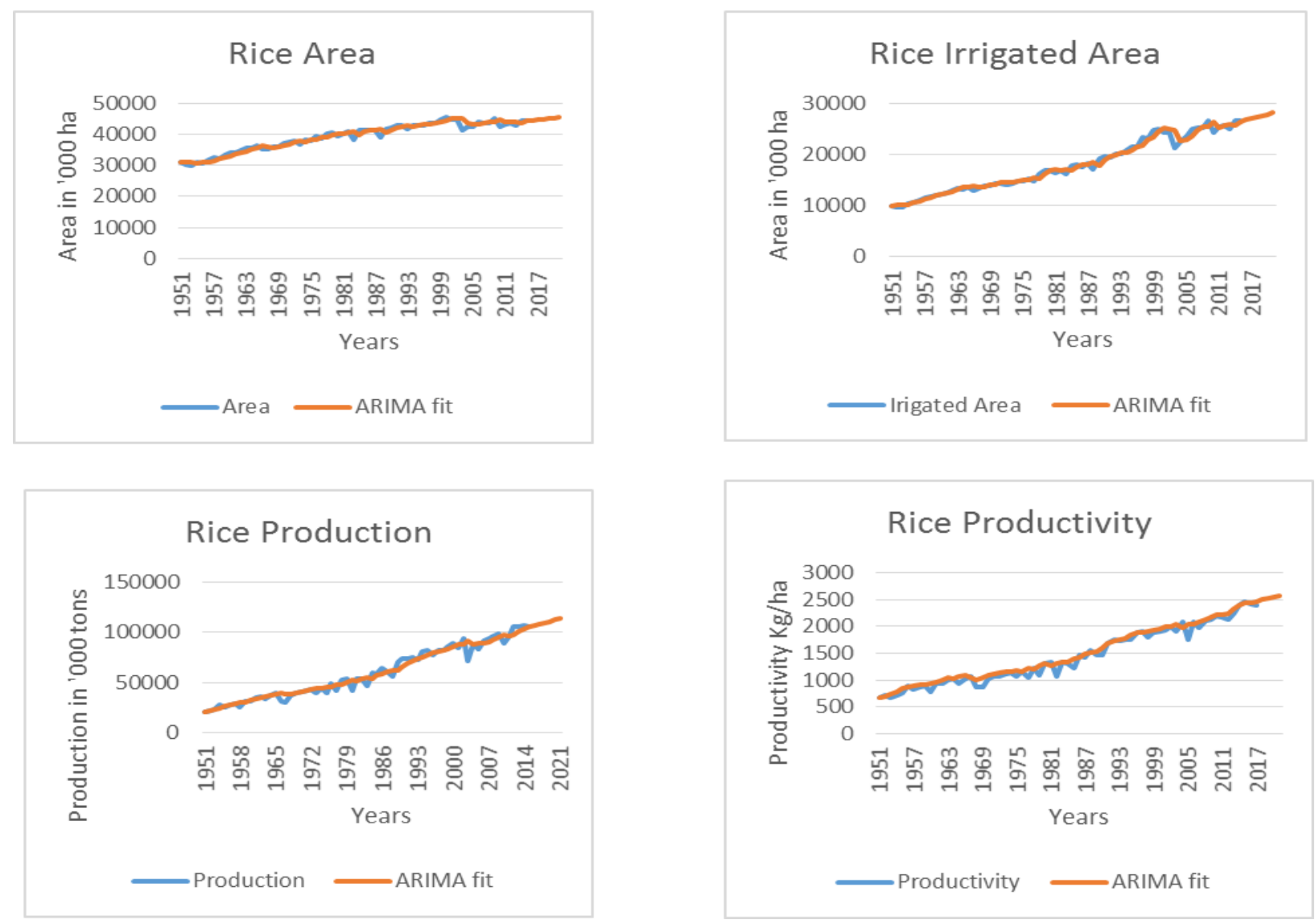
Fig.2 Observed and predicated area, irrigated area, production and productivity of wheat
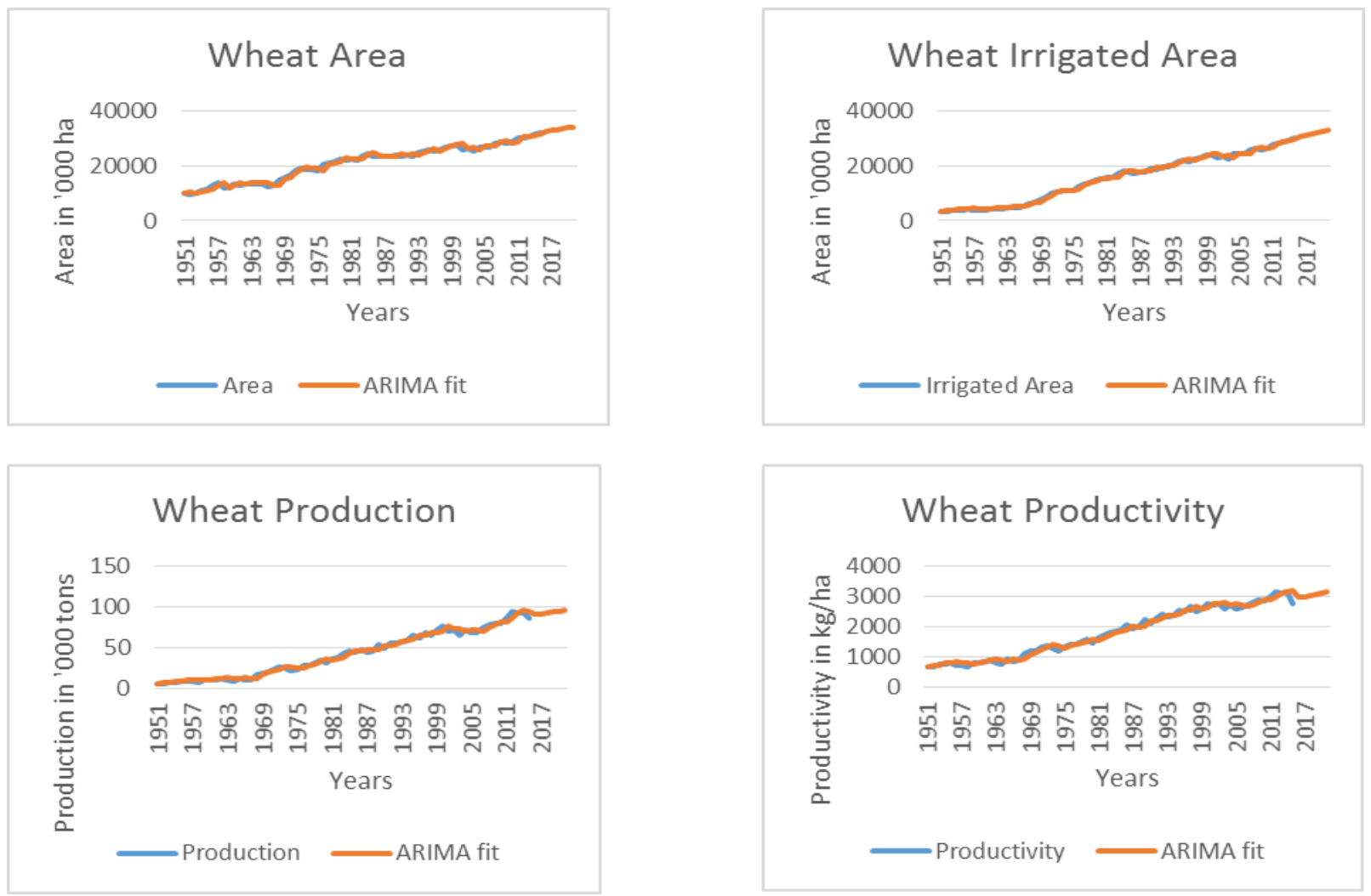

Fig.3 Observed and predicated area, irrigated area, production and productivity of maize
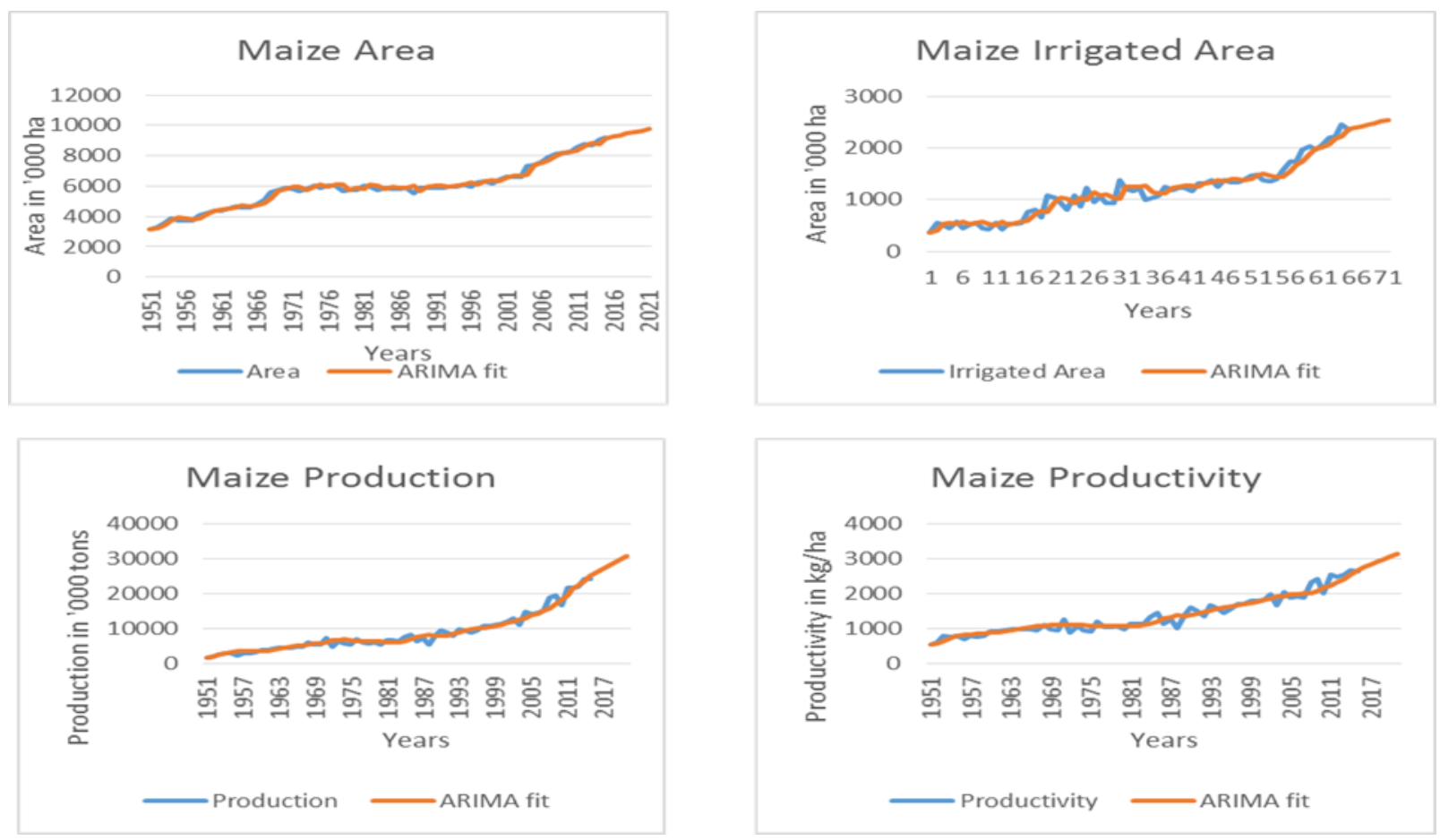
Once the order of $\mathrm{p}, \mathrm{d}$, and $\mathrm{q}$ are identified, next step is to specify appropriate regression model and estimate it. The estimated results of the ARIMA model are reported in Table 5. The detail result of the accuracy of the model is mentioned in the Table 6. The different parameter like RMSE, MAE, MAPE etc. is used to check the accuracy of the model.

Once the three previous steps of ARIMA model is over, then we can obtained forecasted values by estimating appropriate model, which are free from problems. The forecasting technique used to deliver a common idea concerning uncertain or unknown events. The main purposes of making forecast are to gain knowledge about uncertain events that are important to our present decisions. To analyse the growth pattern and to make the best forecast of rice, wheat and maize area, irrigated area, production and productivity using ARIMA technique is one of the best method in India. The forecasted values obtained from ARIMA model are reported in Tables 7, 8 and 9. The forecasted values are reported for a maximum 6 years as too much long term forecasting might not be appropriate. We forecasted area, irrigated area, production and productivity of rice, wheat and maize up to 2021. Figures 1, 2 and 3 shows fitted and forecasted value of rice, wheat and maize.

The forecast indicates the performance of rice, wheat and maize production for the next 6 years up to 2021. The result reveals that the yield of rice, wheat and maize in India would be 2.57 tons/ha, 3.14 tons/ ha and 3.13 tons/ha in 2021 respectively. The total production of rice, wheat and maize will be increased by 5319 thousand tons, 5.5 thousand tons and 3838 thousand tons in total respectively. It also emphasizes the need for increase in the per hectare yield of these crops in India in order to get a sustainable development of Agriculture.

\section{References}

Awal, M. A., and Siddique, M. A. B., 2011. Rice production in Bangladesh employing by ARIMA model. Bangladesh Journal of Agricultural Research.36 (1): 51-62.

Box, G. E. P., and Jenkins, G. M., 1976. Time Series Analysis forecasting and control. San Francisco, CA, Colorado State University, Fort Collins, Co.

Celik, S., 2016. Forecasting production of some cereal in turkey by time series analysis.International Journal of Information Research and Review.3 (10): 2887-2897.

Chatfield, C., 1988. What is the 'best' method of forecasting? Journal of Applied Statistics.15 (1): 19-38.

Debnath, M. K., Bera, K., and Mishra, P., 2013. Forecasting area, production and yield of cotton in India using ARIMA model. Research \& Reviews: Journal of Space Science \& Technology. 2(1): 1620.

Hafner, S., 2003. Trends in maize, rice, and wheat yields for 188 nations over the past 40 years: a prevalence of linear growth. Agriculture. ecosystems \& environment.97 (1): 275-283.

Iqbal, N., Bakhsh, K., Maqbool, A., and Ahmad, A. S. 2005. Use of the ARIMA model for forecasting wheat area and production in Pakistan. Journal of Agriculture and Social Sciences. 1(2): 120-122.

Joshi, P. K., 2005. Maize in India: Production systems, constraints, and research priorities. CIMMYT.

Khatkar B.S., Chaudhary N. and Dangi P., 2016. Production and Consumption of Grains: India. In: Wrigley, C., Corke, H., and Seetharaman, K., Faubion, J., (eds.) Encyclopedia of Food Grains, $2^{\text {nd }}$ Edition, 367-373. Oxford: Academic Press. 
Michel, L., and Makowski, D., 2013. Comparison of statistical models for analyzing wheat yield time series. PloS one.8 (10): e78615.

Rachana, W., Suvarna, M., and Sonal, G. 2010. Use of ARIMA Model for Forecasting Pigeon Pea Production in India, International Review of Business and Finance, 2(1), 97-102.
Sahu, P. K., Mishra, P., Dhekale, B. S., Vishwajith, K. P., and Padmanaban, K., 2015. Modelling and Forecasting of Area, Production, Yield and Total Seeds of Rice and Wheat in SAARC Countries and the World towards Food Security. American Journal of Applied Mathematics and Statistics, 3(1): 34-48.

\section{How to cite this article:}

Nalinikanta Choudhury, Sumeet Saurav, Rajeev Ranjan Kumar and Neeraj Budhlakoti1. 2017. Modelling and Forecasting of Total Area, Irrigated Area, Production and Productivity of Important Cereal Crops in India towards Food Security. Int.J.Curr.Microbiol.App.Sci. 6(10): 2591-2600. doi: https://doi.org/10.20546/ijcmas.2017.610.305 